2-1-1998

\title{
Reputation: A Vital Asset for Real Estate Practitioners
}

Trevor C. W. Farrow

Osgoode Hall Law School of York University, tfarrow@osgoode.yorku.ca

Follow this and additional works at: http://digitalcommons.osgoode.yorku.ca/scholarly_works

Part of the Property Law and Real Estate Commons

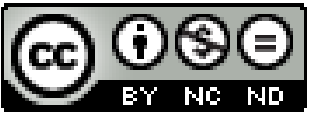

This work is licensed under a Creative Commons Attribution-Noncommercial-No Derivative Works 4.0 License.

\section{Repository Citation}

Farrow, Trevor C. W., "Reputation: A Vital Asset for Real Estate Practitioners" (1998). Articles \& Book Chapters. Paper 1931.

http://digitalcommons.osgoode.yorku.ca/scholarly_works/1931

This Article is brought to you for free and open access by the Faculty Scholarship at Osgoode Digital Commons. It has been accepted for inclusion in Articles \& Book Chapters by an authorized administrator of Osgoode Digital Commons. 
by Trevor C. W. Farrow

Smith:I know the market is tum-

ing around; but bow is be making so

much money?"

Jones: Selling property is bis strong suit, bonesty and ethics are not. He will say anything at all to make a sale.

In the November edition of Canadian REALTOR News, an article entitled "Beware of Haunted Houses" written by John Koch dealt with the issue of slander of title: false statements about title to or the quality or value of real or personal property.

Equally problematic are defamatory statements spoken or written about people or companies.

The Code of Ethics and Standards of Business Practice prohibits REALTORS from making defamatory comments about other REAITORS. Article 22 of the code, for example, provides in part that a REALTOR "shall never publicly discredit a competitor". Anyone who breaches the code may be subject to disciplinary proceedings by their real estate board.

In addition to this, however, defamatory comments may also be the subject of a legal action. That is the focus of this anticle:

Comments made concerning the reputation of a co-worker or a comperiw for, wiether witten or spoken, can te problenutic, both for the speaker ftid for the subject Iside from the obvious potential damage to the reputation of the person about whom the comments are made, the speaker or author of a defamatory comment, no matter how "off the cuff", may find himself or herself embroiled in a painstaking and expensive defamation lawsut.

\section{DEFAMATION}

What makes a statement defamatowy? Clearly the statement made during the hypothetical "water cooler" conversation set out above (loosely adopted from a scenario that was considered by the Ontario Court of Appeal some years ago) is defamatory.

In fact basically any false statement which tends to discredit a person is defamatory. For a statement to be actionable at law, however, not only must it be defamatory, but it also must be made or "published" to, or received by, a third party, either in witing or by spoken word.

\section{LIBEL AND SLANDER}

The law generally distinguishes between spoken and written words. Subject to certain exceptions defamatory words spoken about an individual are referred to as slander; defamatory words witten about an individual are referred to as libel other than the obvious difference in form, the most significant distinction between libel and slander is that where defamatory comments are written about a person, damage to that person need not be proven, it is presumed

The law has developed in this way primarily because of the difficulty in proving the nature and extent of damage suffered as a result of a defamatory written publication. Where defamatory words are spoken about a person, damage must typically be proven.

Slander is, therefore, often a more difficult tort to establish in court.

However; as an exception to the general nule, spoken words which tend to diseredit an indridual in the context of his or her trade or profession, like

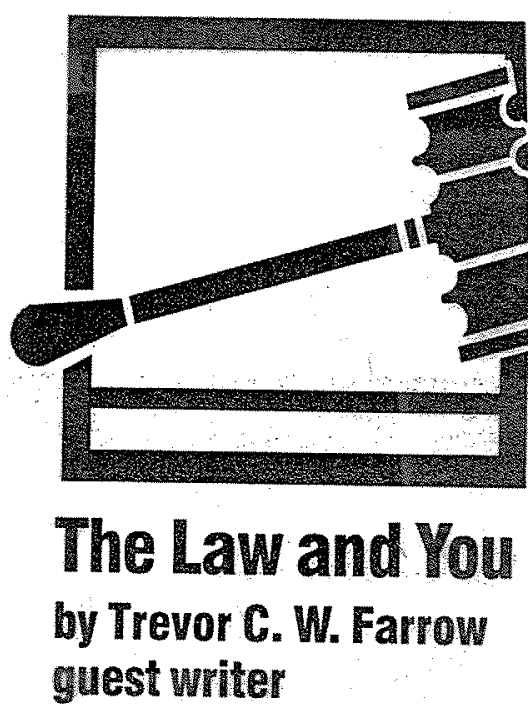

our hypothetical conversation about the unethical real estate agent outlined above, are, like libel, typically actionable without the proof of specific damase

\section{DEFAMATION GLAMIS}

In our hyohetucal sitution, wond gets around to the allegedly "unethical" agent that Smith and Jones are telling agents and clients that he is dishonest and unethical He sues. He can establish that the words are capable of a defamatory meaning, that the words refer to him and have been uttered or distributed to a third person.

Damage is presumed, and the facivy of the statements is presumed What defences are available to Smith and rinos?

\section{DEFENCES:}

(i) Justification

Truth is an absolute defence to a claim of defamation. No matter how embarrassing or damaging a statement may be, as long as it is true, no claim for defamation will succeed. In our hypothetical, provided Smith and Jones can prove that the agent is, in fact, dishonest and unethical, which has led to. the receipt of noome, the statements 
made by the agents, no matter low they are motivated to make the statements, will be protected by the law

The person making the statements will, however have the onus of proving the truth of the statements, and if he or she fails, the fact that truth or "ustification" is pleaded as a defence may be seen as a restatement or "republication" of the offending statements and may aggravate any damage award

(ii) Fair Comment

Opinions faurty expressed on matters of public interest, provided they are based on ture facts are protected by the defence of far comment Gritieal to the defence is the element of "public interest".

Disputes among individuals or between discrete groups typically do not qualify. General public interest must be proven. Generally speaking, for the defence of fair comment to succeed, the statements complained of must be in the form of an opinion, the opinion must be based on underlying facts, the facts must be true, and the comments must be fair and made in good faith based on the honest opinion of the person making the statements.

The defence of fair comment can be defeated if the plaintiff can establish that the statements were made maliciously:

As John Koch indicated in his November article, malice is a conplex legal concept In one case it has been defined as an intent to injure a person without just cause or excuse, or some dishonest or otherwise improper motive.

In our hypothetical, if either Smith or Jones are motivated by anything other than honest or proper intentions, the defence of fair comment will likely fail.

(iii) Qualified Privilege

Certain defamatory statements, wen if untrue, may in any event be protected by the law if they are made by one person to another where the person mak ing the statement has a duty or interest in making the statement and the recipient has a corresponding interest in receiving the statement.
The duty to make the statement can be a legal, social or moral duty, and can be found in the context of both public and private affairs. The defence of qualified privilege can be defeated if it is found that the statement was made maliciously or with a reckless disregard for the trith.

If the person making the statement is motivated by self-interest or malice and intends to harm the business or reputation of the other agent, or even if the person thought the comment was true but made no effort to confirm the truth of the statement, this defence will likely not be available

It is therefore difficult to establish a qualified privilege defence in cases involving competitors and commercial advantage.

(iv) Other Defences

In addition to the above-mentioned defences, other defenoss exist to defend a claim of defamation. The defence of "absolute privilege" is available for statements made in the course of certain proceedings, including parliamentary or state proceedings, provincial legislative proceedings and judicial proceedings, no matter how untrue or damaging the statements may be

Statutory protections are available for fair and accurate reports made of such proceedings. There are also other defences including statutory defences for statements and reports made by newspapers and broadcasters.

Limitation periods also provide time limits within which the various types of defamation claims must be made.

\section{CONCLUSION}

In the case upon which our hypothetical is based, a letter was typed by a stenographer and sent to the agent accusing him of dishonesty. No one else but the agent received the letter. The trial judge awarded damages for defamation.

The Court of Appeal upheld the decision but reduced the award to nominal damages based on the limited distribution. It was found that the defence of qualified privilege did not apply as between the sender and the recipient.

Wrom this introductory look at the law of defamation (primarily based on Ontario defamation law), it can be seen that what may appear on its face to be a legitimate concern discussed with colleagues or clients can be the subject of a successful defamation action.

There may be some circumstances where a speaker may be justified in disseminating defamatory intormation to a third party. However, defamation is a technical and complex area of kaw.

Further, the successful defamation plaintiff has received an average award of approximately $\$ 20,000$ in Canada over the past number of years, awards can be much higher.

As such, if you find yourself inclined to make a comment that could possibly damage the reputation of another person or company, notwithstanding your good intentions, make sure the facts on which the comment is based are true.

Seeking the advice of counsel before disseminating possible defamatory information is always advisable.

Thetor Farrow practices civil litigation at Tory Tory DesLauriers E Binnington, Toronto, with a focus on corporate commercial litigation, including defamation litigation. He may be contacted at (410) 865-0040. 